\title{
PENINGKATAN KUALITAS PEMBELAJARAN KERAJINAN BATIK DENGAN MENGGUNAKAN MEDIA INTERAKTIF BERBASIS KOMPUTER MULTIMEDIA
}

\section{Ismadi}

Fakultas Bahasa Seni Universitas Negeri Yogyakarta

Abstrak

Penelitian ini bertujuan untuk mendeskripsikan proses pembelajaran dan peningkatan hasil pembelajaran kerajinan batik dengan menggunakan media interaktif berbasis komputer multimedia. Subjek penelitian adalah mahasiswa semester III Program Studi Pendidikan Seni Kerajinan Jurusan Pendidikan Seni Rupa FBS UNY sebanyak 20 orang. Penelitian ini didesain sebagai Penelitian Rupa FBS UNY sebanyak 20 orang. Penelitian ini didesain sebagai Penelitian
Tindakan Kelas (PTK) dengan langkah penelitian mengacu pada model yang Tindakan Kelas (PTK) dengan langkah penelitian mengacu pada model yang
diterapkan oleh Kemmis dan Metaggart dan dilaksanakan 2 siklus. Pengambilan diterapkan oleh Kemmis dan Metaggart dan dilaksanakan 2 siklus. Pengambilan dianalisis secara deskriftif kualitatif. Hasil penelitian tindakan I menunjukkan bahwa pemahaman teori dasar-dasar membatik dengan tes pilihan ganda dengan 10 soal, mahasiswa mendapat nilai rata-rata 6,6. pelaksanaan tindakan I masih mengalami permasalahan dalam pembelajaran kerajinan batik, hal ini ditanda dengan nilai rata-rata mahasiswa yang masih kurang. Oleh karena itu perlu diadakan tindakan II. Tindakan II dilakukan setelah merevisi media pembelajaran interaktif yang dikembangkan oleh peneliti. Pelaksanaan tindakan II ini sudah menunjukkan ada peningkatan yang signifikan, yaitu rata-rata mahasiswa suda mencapai nilai 7. oleh karena itu, dengan adanya peningkatan nilai pada tindakan II ini, maka dianggap sudah tidak perlu lagi dilakukan tindakan IIII. Analisis data menunjukkan bahwa media pembelajaran yang interaktif dapat mempengaruh hasil pembelajaran yang cukup besar. Hal in dibuktikan dengan nilai rata-rata hasil tes yang diperoleh mahasiswa pratindakan adalah 4,5, tindakan I adalah 6,6 dan tindakan II adalah 7.

Kata kunci: kerajinan batik, pembelajaran, dan media interaktif

\section{PENDAHULUAN}

Latar Belakang

Lembaga pendidikan akan berkembang secara konsisten dan akan mampu bersaing di era informasi apabila mampu meletakkan aspek kualitas secara sadar dalam kegiatan pendidikan dan pembelajaran. Kualitas pembelajaran ini perlu dikaji secara terus menerus, karena pada dasarnya terus berkembang secara interaktif sesuai dengan tuntutan kebutuhan masyarakat dan perkembangan teknologi.

Indikator kualitas pembelajaran dapat dilihat dari perilaku pembelajaran tenaga pengajar, perilaku dan dampak pembelajaran mahasiswa, iklim pembelajaran, materi pembelajaran, media pembelajaran dan sistem pembelajaran. 
Penyelenggaraan pembelajaran di Program Studi Pendidikan Seni Kerajinan masih banyak mengalami hambatan. Hambatan tersebut antara lain berasal dari : (a) sarana dan prasarana pembelajaran belum memadai, (b) waktu yang tersedia untuk pembelajaran sangat terbatas, dan (c) kemampuan dosen dalam hal pengembangan materi pembelajaran dan perancangan strategi pembelajaran masih rendah.

Upaya mengatasi berbagai hambatan tersebut salah satunya dengan meningkatkan kemampuan pembelajaran para pendidik dengan membangkitkan dan membangun sikap positif terhadap belajar, yang bermuara pada peningkatan kualitas proses dan hasil belajar. Maka dipandang perlu untuk melakukan inovasi pembelajaran dengan harapan proses pembelajaran dapat lebih berkualitas.

Berdasarkan pengamatan di kelas, kegiatan pembelajaran selama ini kurang adanya penggunaan media yang efektif, metode demonstrasi yang selama ini dilakukan kurang bisa diterima oleh sebagian besar mahasiswa sehingga mengakibatkan terjadinya pembelajaran kurang tuntas. Dilain pihak cukup menyita waktu untuk melakukan perulangan demonstrasi bagi mahasiswa yang kurang bisa memahami. Berawal dari itu, maka perlu adanya pengembangan media pembelajaran. Salah satu media pembelajaran yang tepat dan sesuai dengan kompetensi serta materi kerajinan batik adalah media interaktif berbasis komputer multimedia.

Media tersebut sangat membantu pada proses pembelajaran praktek khususnya kerajinan batik. Dengan media interaktif berbasis kompute multimedia akan selalu ada rekaman multimedia (audio-visual) tentang demonstrasi yang dilakukan dosen pengampu sehingga mahasiswa bisa kapan saja tidak terikat dosen untuk mengetahui demonstrasi yang dilakukan dosen tentang semua kompetensi perkuliahan kerajinan batik dari pembuatan desain batik, persiapan alat dan bahan, proses membatik, pewarnaan, pelorodan sampai finishing.

Sesuai dengan harapan peneliti, maka media pembelajaran atau software yang dibuat tersebut akan diujicobakan dan dianalisis seberapa jauh efektivitas dan efisiensi, serta peningkatannya terhadap kualitas pembelajaran kerajinan batik di Program Studi Pendidikan Seni Kerajinan Jurusan Pendidikan Seni Rupa FBS UNY.

Berdasarkan uraian latar belakang masalah tersebut diatas, masalah penelitian dirumuskan sebagai berikut. Bagaimanakah penggunaan media interaktif berbasis komputer multimedia dapat meningkatkan kualitas pembelajaran kerajinan batik? Secara rinci permasalahan tersebut dapat diuraikan sebagai berikut. (1) bagaimanakah penerapan media interaktif berbasis komputer multimedia yang dapat meningkatkan kualitas pembelajaran kerajinan batik? Dan (2) bagaimanakah menginventarisir kendala-kendala sebagai bahan pertimbangan untuk refleksi yang dapat digunakan dalam pengembangan media interaktif multimedia berikutnya.

\section{Tujuan Penelitian}

Penelitian ini untuk mendiskripsikan media interaktif multimedia dan pengaruhnya terhadap peningkatan pembelajaran dengan indikator keberhasilan prestasi hasil belajar mahasiswa pada mata kuliah kerajinan batik. Secara rinci penelitian bertujuan untuk, (1) mendeskripsikan penerapan media interaktif berbasis komputer multimedia dalam pembelajaran kerajinan batik dan (2) mendeskripsikan kendala-kendala sebagai bahan pertimbangan untuk refleksi yang dapat digunakan dalam pengembangan media interaktif berbasis komputer multimedia berikutnya.

\section{Kajian Teori}

\section{Peranan Media dalam Pembelajaran Kerajinan Batik}

Pelaksanaan proses pembelajaran sebaiknya dosen menggunakan media atau alat bantu dalam menyampaikan materi pelajaran, agar materi mudah dan jelas diterima siswa. Gerlach \& Ely (1980: 241) menyatakan bahwa media apabila dipahami secara garis besar adalah manusia, materi, atau kejadian yang membangun kondisi dan membuat siswa mampu memperoleh pengetahuan, keterampilan, dan sikap. Dari pengertian tersebut di atas, maka dapat dikatakan bahwa dosen, buku teks, dan lingkungan dimana terjadinya proses belajar dapat dikatakan sebagai media.

Yusufhadi Miarso, dkk. (1994: 201) memberikan batasan bahwa media merupakan semua bentuk dan saluran yang digunakan dalam proses penyampaian informasi. Sedangkan Heinich, et al. (1996: 8), menjelaskan bahwa media merupakan sebuah perantara yang mengantar informasi antara sumber dan penerima, misalnya: $\mathrm{tv}$, film, foto, radio, rekaman, audio, audio visual, gambar yang proyeksikan, bahan-bahan cetakan dan sejenisnya merupakan sebuah media kominkasi.

Selanjutnya Azhar Asryad (2003: 4) menyatakan bahwa media merupakan komponen sumber belajar atau wahana fisik yang mengandung materi instruksional di lingkungan siswa yang dapat merangsang siswa untuk belajar. Oleh karena itu, dengan adanya media yang memadai dan sesuai dengan tujuan pembelajaran, serta metode yang digunakan dalam proses pembelajaran. Maka hal ini dapat merangsang kegiatan pembelajaran, baik dari pihak guru maupun siswa.

Berdasarkan beberapa pendapat di atas, maka dapat disimpulkan bahwa media pembelajaran merupakan segala sesuatu yang dapat digunakan untuk menyampaikan pesan dari dosen kepada mahasiswa agar dapat merangsang pikiran, perasaan, perhatian, minat, dan motivasi mahasiswa, sehingga proses 
pembelajaran dapat berjalan secara efektif dan efisien serta tujuan pembelajaran dapat dicapai dengan baik.

\section{Media Interaktif dalam Kawasan Teknologi Pembelajaran.}

Konsep teknologi pembelajaran menurut AECT (Association for Educational Communicatoins and Technology) adalah Instructional technology is the theory and practice of design, development, utilization, menegement, and evaluation of processes and recources for learning (Seels \& Richey, 1994: 1).

Berdasarkan definisi di atas maka dapat disimpulkan bahwa struktur kawasan teknologi pendidikan meliputi perencanaan, pengembangan, pemanfaatan, pengelolaan, dan evaluasi. Untuk lebih jelasnya dapat dilihat pada gambar 1.

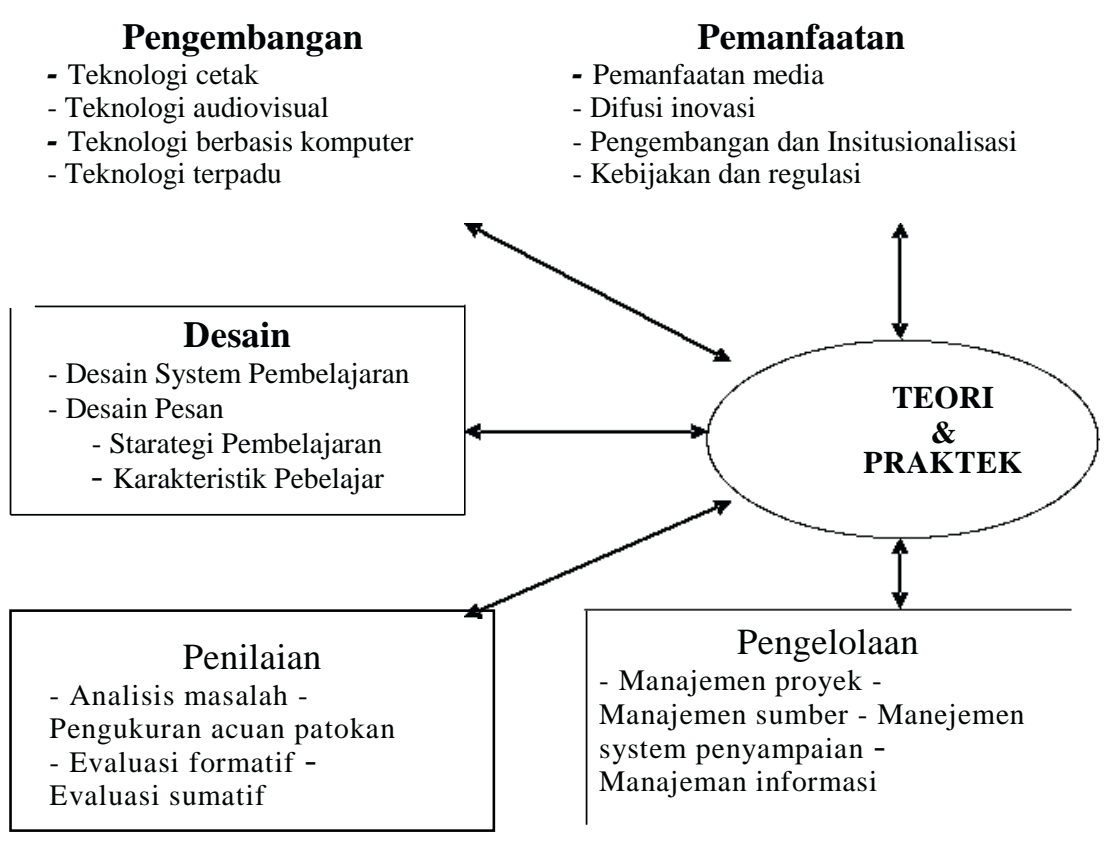

Gambar 1. Kawasan Teknologi Pendidikan (Seels dan Richey, 1994: 26)

Berdasarkan bagan gambar 1 tersebut, dapat diketahui bahwa letak penerapan media interaktif yang akan digunakan oleh peneliti terletak pada kawasan pemanfaatan, yaitu pemafaatan media, dalam hal ini media pembelajaran berbasis komputer. Pembelajaran berbasis komputer merupakan cara memproduksi dan menyampaikan bahan dengan mengunakan perangkat yang bersumber pada mikro prosesor. Pesan disimpan secara elektronik dalam bentuk data digital kemudian disajikan kepada siswa dengan menggunakan display layar komputer (Yusufhadi Miarso, dkk., 1994: 42).

\section{Manfaat Media Interaktif Berbasis Komputer dalam Pembelajaran}

Winkel (1996: 288-289) mengemukakan bahwa penggunaan komputer dalam pengajaran di dalam kelas dapat berperan sebagai dosen karena materi pelajaran telah diprogramkan dan terdapat dalam ingatan komputer (memory). Mahasiswa tidak lagi berinteraksi dengan seorang manusia yang menjadi guru, melainkan berinteraksi dengan komputer yang berperan sebagai dosen dan memberikan tanggapan terhadap jawaban atau gagasan dari mahasiswa (computer assisted instructional), sejumlah mahasiswa dapat mempelajari materi yang sama pada waktu yang sama pula; masing-masing mahasiswa menangani suatu terminal yang dihubungkan dengan komputer pusat.

Lebih lanjut dijelaskan oleh Sunaryo Soenarto (2002: 186) bahwa komputer digunakan dalam pembelajaran dapat memberikan manfaat sebagai berikut:

1) Penggunaan perangkat lunak jauh lebih baik untuk menyajikan bahan ajar yang mempunyai struktur baku seperti yang matematika.

2) Peran komputer bergeser dari media yang digunakan untuk menyajikan bahan ajar menjadi media yang mampu memainkan sebagai sumber belajar mahasiswa.

3) Peran komputer telah menggeser konsep belajar di ruang kelas menuju konsep belajar di ruang cyber dalam konteks lingkungan yang lebih luas.

Berdasarkan penjelasan di atas, dapat disimpulkan bahwa komputer sebagai bentuk penerapan teknologi komputer dalam pembelajaran dalam bentuk media interaktif dapat meningkatkan motivasi belajar mahasiswa, memberikan feed back kepada mahasiswa, mengatasi kelemahan-kelemahan dalam belajar kelompok (klasikal), mengatasi rasa malu mahasiswa yang lambat atau kurang konsentrasi dalam belajar, serta sangat mendukung pembelajaran individual dalam mengadapi era pendidikan modern.

\section{Mata Kuliah Kerajinan Batik}

Mata kuliah Kerajinan Batik merupakan mata kuliah yang memberikan kemampuan kepada mahasiswa untuk memahami bahan, teknik, dan motif batik. Materi perkuliahan mencakup jenis bahan, karakteristik bahan, kegunaan bahan, jenis alat, fungsi alat, teknik batik. Kegiatan belajar mengajar dilaksanakan dengan perkuliahan teori dan praktik.

Sedangkan mata kuliah Kerajinan Batik lanjutan memberikan kemampuan kepada mahasiswa untuk membuat desain sampai dengan membuat prototipe kerajinan batik dengan bahan kayu dan kain. Materi perkuliahan 
mencakup desain dan presentasi karya kerajinan batik. Kegiatan belajar mengajar dilaksanakan dengan perkuliahan teori dan praktik. Evaluasi dilakukan dengan tes, karya tugas harian, dan presentasi karya.

Untuk mata kuliah Kerajinan Batik tahap akhir memberikan kemampuan kepada mahasiswa untuk memahami dan membuat konsep, memilih bahan untuk menemukan bentuk baru. Materi perkuliahan mencakup konsep, desain, dan presentasi karya. Kegiatan belajar mengajar dilaksanakan dengan perkuliahan teori, praktik dan pengkajian serta pengamatan di lapangan. Evaluasi dilakukan dengan tes, konsep, dan presentasi karya ( Tim Kurikulum, 2002: 22).

\section{METODE PENELITIAN}

Pendekatan penelitian ini adalah penelitian tindakan (action research), karena penelitian ini bertujuan untuk meningkatkan pembelajaran dengan memberikan tindakan alternatif yaitu berupa media interaktif berbasis komputer multimedia sebagai penerapan teknologi dalam pembelajaran kerajinan batik. Elliot dan Suwarsih Madya (1994: 1) mengatakan bahwa penelitian tindakan adalah kajian tentang situasi sosial dengan maksud untuk meningkatkan kualitas tindakan di dalamnya, seluruh prosesnya adalah merupakan telaah, diagnosis, perencanaan, pemantauan dan pengaruh hubungan antara evaluasi dan profesional. Inti dari penelitian ini terletak pada tindakan-tindakan alternatif yang dibuat oleh peneliti, kemudian diujicobakan dan dievaluasi apakah tindakan alternatif ini dapat memecahkan persoalan yang dihadapi dalam pembelajaran.

Dalam penelitian ini yang menjadi subjek penelitian adalah: mahasiswa kelas A Semester III Program Studi Pendidikan Seni Kerajinan Jurusan Pendidikan Seni Rupa FBS UNY. Pengumpulan data dalam penelitian ini ada empat macam kegiatan, yaitu: (1) tes, ( 2) observasi, (3) wawacnara, dan (4) dokumentasi. Kegiatan observasi dilakukan untuk mendapatkan data tentang aktivitas mahasiswa dalam pembelajaran dengan menggunakan media interaktif, serta bagaimana aktivitas dosen dalam pembelajaran berlangsung. Kegiatan wawancara dilakukan dengan cara wawancara langsung dengan dosen pengampu yang mengajar mata kuliah kerajinan batik, yang bertujuan untuk mendapatkan data tentang pembelajaran kerajinan batik, yang meliputi aktivitas dosen dalam pembelajaran, metode yang digunakan, serta fasilitas pembelajaran dan kesulitankesulitan yang dihadapi oleh siswa. Dokumentasi dalam penelitian ini adalah berupa hasil catatan lapangan, daftar hadir, hasil karya mahasiswa, hasil tes tertulis, dan foto saat penelitian sedang berlangsung.

Seluruh data yang terkumpul dianalisis dengan teknik statistik deskriptif kuantitatif dan kualitatif. Data yang dianalisis secara kualitatif adalah data dari hasil observasi dan wawancara, sedangkan data yang dianalisis secara kuantitatif adalah data yang berdasarkan penilaian hasil tes tentang materi kerajinan batik.
Setelah itu diadakan refleksi dan perbandingan antara hasil pra tindakan dengan post tindakan. Hal ini dilakukan untuk mengetahui apakah tindakan sudah cukup atau sudah dapat meningkatkan pembelajaran atau masih ada perbaikanperbaikan untuk siklus berikutnya.

\section{HASIL PENELITIAN DAN PEMBAHASAN \\ Hasil Penelitian}

Subjek terdiri dari 20 mahasiswa, 11 mahasiswa laki-laki dan 9 mahasiswa perempuan adapun daftar siswa dapat dilihat dalam lampiran daftar nilai. Subjek mempunyai kecenderungan berkelompok, dalam belajar mereka selalu terlihat ramai dan gaduh. Begitu juga dalam mengerjakan tugas, sehingga dosen sering sekali menegur mahasiswa agar serius atau tidak ramai dalam belajar. Saat perkuliahan dimulai masih banyak mahasiswa yang belum hadir tepat pada waktunya, hal ini disebabkan jam kuliah kerajinan batik ada pada jam ketiga. Pada dasarnya mahasiswa menghendaki adanya perubahan peningkatan pembelajaran kerajinan batik sehingga mereka lebih serius dalam mengikuti kuliah (wawancara dengan mahasiswa 16 September 2009).

Dosen yang mengampu mata kuliah kerajinan batik berjumlah empat, dua diantaranya terbentuk dalam sebuah tim yaitu Ibu Hasnawati, M.Pd.dan Ismadi, S.Pd. beliau berdua merupakan dosen yunior di Jurusan Pendidikan Seni Rupa FBS UNY. Dalam proses pembelajaran, beliau sesering mungkin memberikan motivasi pada mahasiswanya, namun dengan berbagai macam karakteristik mahasiswa, ada beberapa mahasiswa yang kurang memperhatikan penjelasan dosen.

Mata kuliah ini merupakan perkulahan praktik, oleh karena itu dalam dalam penyampaian materi perkuliahan didukung dengan fasilitas yang relevan. Adapun fasilitas yang digunakan dalam proses pembelajaran kerajinan batik adalah ruang praktek batik, seperangkat alat praktek membatik sebanyak 10 unit untuk kapasitas mahasiswa 20 yang cukup memadai. Di ruang kelas dilengkapi pula sarana papan tulis sebagai media menulis apabila ada sesuatu materi yang penting atau perlu ditekankan pada mahasiswa. Selain itu fasilitas LCD dan laptop pun disediakan guna membantu proses pembelajaran.

\section{Pelaksanaan Tindakan Penelitian}

Kegiatan observasi dilaksanakan selama dua pertemuan yaitu tanggal 16 dan 30 September, meliputi proses belajar mengajar kerajinan batik, presensi mahasiswa, situasi kelas, juga mengenai fasilitas kelas yang ada seperti tersedianya alat praktek, dan belum tersedianya media pembelajaran kerajinan batik (Wawancara Tanggal 16 September 2009 dengan Ibu Hasnawati, M.Pd, beliau adalah dosen mata kuliah kerajinan batik). 
Kegiatan observasi diawali dengan perkenalan peneliti kepada mahasiswa kelas A Semester III Program Studi Pendidikan Seni Kerajinan Jurusan Pendidikan Seni Rupa FBS UNY dengan tujuan agar mahasiswa menjadi akrab dengan peneliti, juga mengungkap minat anak dalam menerima perlakuan yang menantinya akan diberikan.

Materi tindakan dalam penelitian ini disesuaikan dengan silabus. Peneliti mengadakan diskusi dengan dosen mata kuliah tentang materi yang sebaiknya dikemas dalam sebuah media pembelajaran kerajinan batik yang lebih ditekankan pada pemahaman teori dasar dan rekaman saat dosen demonstrasi proses membatik.

Tindakan siklus I dilakukan pada tanggal 7 Oktober 2009. Sebelum tindakan diberikan, terlebih dahulu peneliti memberikan soal-soal tentang teori dasar kerajinan batik. Hal ini dilakukan untuk mengetahui sejauh mana pemahaman mahasiswa terhadap teori-teori dasar kerajinan batik. Aktivitas yang dilakukan pada kegiatan awal, yakni peneliti dan dosen bersama-sama mempersiapkan mahasiswa untuk mengikuti pembelajaran, menyiapkan alat untuk belajar yaitu seperangkat laptop dan LCD, selain itu memberikan apersepsi pada siswa akan pentingnya materi yang akan dipelajari. Setelah kegiatan awal dilanjutkan dengan kegiatan inti. Pada kegiatan inti, peneliti dan dosen mempersiapkan untuk membuka media pembelajaran yang ada pada laptop. Media pembelajaran berisi bahan ajar yang di antaranya adalah rekaman demonstrasi urutan proses pembuatan karya kerajinan batik. Apabila ada sesuatu hal yang kurang dipahami oleh mahasiswa, maka mahasiswa diberi kesempatan untuk bertanya. Kemudian mahasiswa diberi media pembelajaran dalam bentuk kepingan CD dengan harapan dapat belajar sendiri melalui media tersebut. Pada kegiatan akhir, mahasiswa menjawab beberapa soal yang terdapat dalam media pembelajaran, hal ini dilakukan untuk mengetahui sejauh mana pemahaman mahasiswa setelah belajar dengan bantuan komputer.

Selama kegiatan pembelajaran berlangsung, peneliti mencatat bagaimana reaksi mahasiswa selama mengikuti proses pembelajaran dengan menggunakan media pembelajaran yang interaktif dalam bentuk kepingan CD. Monitoring atau pemantauan yang dilakukan peneliti terhadap subjek penelitian pada pelaksanaan tindakan tindakan putaran pertama ini adalah sebagai berikut. Pertama, monitoring terhadap mahasiswa: selama proses pembelajaran berlangsung, mahasiswa terlihat antusias mengikuti pembelajaran yaitu dengan memperhatikan dengan seksama dan bagi yang memiliki laptop atau komputer membuka sendiri media pembelajaran tersebut sesuai dengan arahan peneliti. Kedua, hasil monitoring terhadap media: walaupun media yang dibuat oleh peneliti masih sederhana, namun mahasiswa tetap terlihat enjoy dalam mengikuti pembelajaran. Hal ini dikarenakan mungkin selama ini mereka belum pernah belajar memahami materi kuliah yang dikemas dalam bentuk kepingan $\mathrm{CD}$.

Pelaksanaan proses pembelajaran kerajinan batik dengan menggunakan media interaktif pada tindakan I terlaksana dengan baik. Hubungan baik terjadi antara peneliti dan subjek penelitian (mahasiswa), sehingga mempermudah pelaksanaan tindakan. Pelaksanaan tindakan pertama ini belum mendapatkan hasil yang memuaskan, karena setelah mahasiswa belajar melalui media tersebut, peneliti memberikan soal-soal yang berkaitan dengan materi yang terdapat dalam media yang dibuat. Namun ternyata walaupun mahasiswa begitu antusias dalam mengikuti proses pembelajaran, masih banyak mahasiswa yang mendapat skor dibawah rata-rata. Hal ini dikarenakan hanya ada sedikit mereka yang memiliki komputer ataupun laptop (Wawancara dengan mahasiswa tanggal 7 Oktober 2009).

Hasil yang diperoleh dalam tindakan pertama tentang pemahaman teori dasar kerajinan batik dengan tes pilihan ganda dengan 10 soal, siswa mendapatkan nilai dengan rata-rata 6,6 hal ini dapat dilihat pada lampiran hasil evaluasi tes pilihan ganda pada tindakan I. Apabila dilihat dari nilai rata-rata kelas pada tindakan satu masih sangat kurang, oleh karena peneliti melakukan perbaikan media yaitu dengan menambah contoh-contoh dan materi dalam media yang dibuat. Harapan peneliti dengan adanya perbaikan tersebut, mahasiswa dapat lebih memahami teori-teori dasar kerajinan batik dengan baik. Pelaksanaan tindakan I masih mengalami permasalahan dalam hal pembelajaran kerajinan batik, hal ini ditandai dengan nilai rata-rata siswa yang masih sangat kurang. Oleh karena itu perlu diadakan tindakan putaran yang kedua.

Setelah dilakukan perbaikan pada media pembelajaran yang dibuat oleh peneliti, maka dilanjutkan dengan pemberian tindakan yang kedua. Tindakan pada siklus II dilakukan pada tanggal 14 Oktober 2009. Seperti halnya pada tindakan I, pada kegiatan awal peneliti dan dosen bersama-sama mempersiapkan mahasiswa untuk mengikuti pembelajaran, menyiapkan alat praktek dan seperangkat laptop dan LCD, selain itu memberikan apersepsi pada mahasiswa akan pentingnya materi yang akan dipelajari. Adapun materi pada tindakan II ini adalah mengulangi materi sebelumnya.

Pada kegiatan inti tindakan II, peneliti dan dosen mempersilahkan salah satu perwakilan mahasiswa untuk membuka media pembelajaran yang telah diberikan dalam bentuk kepingan CD. Mahasiswa belajar sendiri melalui media tersebut di bawah bimbingan dan arahan peneliti. Apabila ada sesuatu hal yang masih kurang dipahami oleh mahasiswa, maka mahasiswa diberi kesempatan untuk bertanya.

Kegiatan akhir pada tindakan II berupa kegiatan mahasiswa menjawab beberapa soal yang terdapat dalam media pembelajaran, hal ini dilakukan untuk mengetahui sejauh mana pemahaman mahasiswa setelah belajar melalui 
komputer. Setelah selesai, peneliti dan dosen mempersilahkan perwakilan mahasiswa untuk mematikan laptop.

Selama kegiatan pembelajaran berlangsung pada tindakan II ini, peneliti mencatat bagaimana reaksi mahasiswa selama mengikuti proses pembelajaran dengan menggunakan media pembelajaran yang interaktif dalam bentuk kepingan CD. Peneliti melihat dan mencatat perkembangan dan perubahan yang terjadi pada pelaksanaan tindakan ke II ini.

Monitoring yang dilaksanakan pada tindakan II ini tidak jauh berbeda dengan monitoring yang dilaksanakan pada tindakan I, yaitu melihat dan mencatat sejauh mana perkembangan hasil tindakan I dan tindakan II. Monitoring dilakukan dengan menggunakan pedoman observasi, seperti halnya pada tindakan I, berbagai hal yang dimonitoring pada tindakan II terdiri atas keterlihatan mahasiswa dalam proses pembelajaran yang meliputi sikap mahasiswa dalam proses pembelajaran, aktivitas serta motivasi mahasiswa terhadap kuliah, berdasarkan panduan pengamatan.

Pelaksanaan proses pembelajaran kerajinan batik dengan menggunakan media interaktif pada tindakan II terlaksana dengan baik sesuai dengan rencana. Seperti pada pemberan tindakan I hubungan antara peneliti dan subjek penelitian (mahasiswa) terjalin dengan baik, sehingga mempermudah pelaksanaan tindakan II. Pelaksanaan tindakan kedua ini sudah menunjukkan ada peningkatan yang signifikan, yaitu dapat dilihat dari nilai-nilai mahasiswa yang mengalam peningkatan, mulai dari hasil tes sebelum diberi tindakan, tindakan I dan tindakan II. Oleh karena itu, dengan adanya peningkatan nilai tindakan II ini, maka dianggap tidak perlu lagi dilakukan tindakan III.

Untuk lebih jelasnya, perbandingan antara hasil pra tindakan/ per test, tindakan I dan tindakan II dapat dilihat pada tabel berikut ini.

Tabel 2. Perbandingan antara hasil pra tindakan/per test, tindakan I dan tindakan II

\begin{tabular}{ccc}
\hline \multicolumn{3}{c}{ Nilai rata-rata mahasiswa } \\
\hline Pre Test & Tindakan I & Tindakan II \\
\hline 4,5 & 6,6 & 7 \\
\hline
\end{tabular}

\section{Pembahasan}

Dari hasil penelitian di atas dapat dikatakan bahwa sebelum tindakan diberikan, mahasiswa terlihat kurang bersemangat dalam mengikuti pembelajaran kerajinan batik. Berbagai upaya yang dilakukan oleh dosen mata kuliah untuk memotivasi mahasiswa, namun hasilnya juga masih kurang mengalami perubahan pada diri mahasiswa untuk lebih bersemangat mengikuti proses pembelajaran. Hal ini dikarenakan mata kuliah kerajinan batik adalah mata kuliah praktik, oleh karena itu mahasiswa ingin membuat sebuah karya kerajinan batik dengan perpedoman langkah kerja yang telah rekam pada media pembelajaran tersebut.

Hal ini dapat diketahui pada saat penelitian mengadakan observasi di kelas, yaitu apabila dosen menjelaskan tentang materi pembelajaran kerajinan batik khususnya teori-teori dasar kerajinan batik banyak mahasiswa yang kurang memperhatikan. Selain dari hasil observasi, juga terlihat dari hasil test sebelum tindakan yang masih sangat rendah yaitu nilai rata-rata siswa hanya 4,5. Oleh karena itu, penelitian dan dosen bersama-sama membangun semangat mahasiswa agar dapat lebih enjoy mengikuti pembelajaran. Hal yang dilakukan adalah dengan memberikan tindakan yaitu berupa $\mathrm{CD}$ pembelajaran yang interaktif dimana dalam CD tersebut memuat teori-teori dasar kerajinan batik.

Pada dasarnya, subjek penelitian menginginkan adanya perubahanperubahan proses pembelajaran dalam meningkatkan kemampuan mereka dalam berkarya. Namun dengan proses pembelajaran yang konvensional mereka merasa kurang termotivasi untuk membuat sebuah karya yang baik. Setelah dilakukan tindakan I dan tindakan II, dapat diketahui bahwa media pembelajaran yang interaktif dapat mempengaruhi hasil pembelajaran yang cukup besar. Hal ini dibuktikan dengan nilai rata-rata hasil tes yang diperoleh mahasiswa pra tindakan adalah 4,5, tindakan I adalah 6,6 dan tindakan II adalah 7. Peningkatan hasil tes ini dapat terjadi karena adanya perbaikan media yang dikembangkan oleh peneliti, serta rasa enjoy mahasiswa dalam mengikuti proses pembelajaran lebih meningkat dibandingkan dengan siklus sebelumnya. Selain itu, pada setiap pelaksanaan tindakan kerjasama terjalin baik antara dosen dan peneliti. Oleh karena itu, dengan adanya kerjasama ini pemberian tindakan dapat dilakukan dengan baik sesuai dengan perencanaan.

Untuk lebih jelasnya peningkatan hasil tes pilihan ganda dapat dilihat pada grafik gambar 3 berikut:

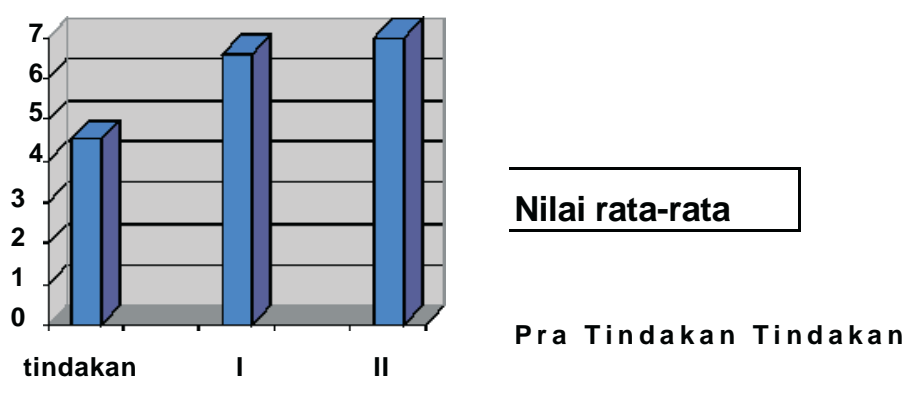

Gambar 3. Grafik Peningkatan Nilai Tes Pilihan Ganda

Dari grafik di atas, dapat dikatakan bahwa media pembelajaran kerajinan batik yang interaktif dapat meningkatkan pemahaman mahasiswa terhadap teori- 
teori yang mendasari pembuatan karya kerajinan batik. Selain itu, selama pemberian tindakan berlangsung proses pembelajaran, mahasiswa begitu antusias mengikuti pembelajaran, lebih mempunyai motivasi belajar serta siswa terlihat lebih enjoy. Hal ini terlihat dari hasil observasi tindakan kelas yang dilakukan oleh peneliti.

\section{SIMPULAN}

Pembelajaran kerajinan batik melalui media interaktif berbasis komputer multimedia sudah mengalami peningkatan sebagai berikut. Pertama, peningkatan pengetahuan dan pemahaman tentang teori-teori dasar kerajinan batik. Kedua, peningkatan aktivitas dalam proses pembelajaran. Ketiga, peningkatan motivasi belajar mahasiswa. Keempat, peningkatan hasil belajar mahasiswa ditandai dengan meningkatnya skor hasil tes antara pra tindakan dan post tindakan.

Pembelajaran kerajinan batik dengan media interaktif merupalan upaya yang harus dikembangkan oleh pihak jurusan. Pembelajaran dengan media interaktif hendaknya dapat diterapkan pada mata kuliah lain, karena dengan media yang interaktif dan memuat berbagai macam contoh-contoh peragaan dalam membatik, maka pesan yang disampaikan akan lebih jelas dan mempuyai daya tarik yang lebih bagi mahasiswa. Berhubung karena waktu banyak digunakan dalam pembuatan media pembelajaran yang interaktif, maka penlitian ini belum mengukur bagaimana peningkatan kualitas karya siswa setelah menggunakan media interaktif, oleh karena itu diharapkan ada lanjutan dari penelitian ini.

\section{DAFTAR PUSTAKA}

Arsyad, Azhar. 2003. Media Pengajaran. Jakarta: Raja Grafindo Persada.

Departemen Pendidikan dan Kebudayaan. 1999. Penelitian Tindakan.

Jakarta: Depdikbud.

Djohar. 2003. Pendidikan Strategik: Alternatif untuk Pendidikan Masa Depan. Yogyakarta: Lesfi.

Djomene, Nian S. 1986. Ungkapan Sehelai Batik. Jakarta: Djambatan.

Gerlach,V. S. and D. P Ely. 1980. Teaching \& Media a Systematic Approach. Englewood Cliffs: Prentice-Hall Inc.

Heinich, et. al. 1996. Intructional Media and Technologies for Learning. New Jersey: Prentice-Hall Inc.

Martin, B dan Dwidjoamiguno, R.P. Warindio, Belajar Melukis Batik dan Motifmotif Batik. Yogyakarta.

Seels, B. B. \& Richey, R. C. 1994. Instructional Technology: the Definition and Domains of the Field. Washington, DC: AECT.

Shcramm, W. 1984. Media Besar dan Media Kecil. Terjemahan Abdul Gafur. Yogyakarta: IKIP Yogyakarta.
STSI. 1994. "Wahana Seni Rupa”. Jurnal Seni Rupa 12, IV, hlm. 38. Yogyakarta: STSI.

Arikunto, Suharsimi . 1983. Manajemen Pendidikan. Jakarta: Rineka Cipta. Sunarto, Sunaryo. 2002. "Relevansi Pengembangan CAI Bidang Pendidikan". Jurnal Carrawala Pendidikan. No. I th. XXI ISSN: 0216-1370. Hal. 180193. Yogyakarta: LPM UNY.

Susanto, S.K. Sewan, 1980. Seni Kerajinan Batik Indonesia. Yogyakarta: Balai besar Penelitian dan Pengembangan Industri Kerajinan dan Batik.

Suwarsih Madya. 1994. Panduan Penelitian Tindakan. Yogyakarta: Lemlit IKIP Yogyakarta. 